UDC: 657

JEL: M40, M41

DOI 10.26906/eip.2019.4(75).1869

\title{
THE ROLE OF ACCOUNTING POLICY IN THE ENTERPRISE MANAGEMENT SYSTEM
}

\author{
Yuliia Myronova*, PhD (Economics), \\ Ilona Siroshtan**, Master-student \\ National University«Yuri Kondratyuk Poltava Polytechnic»
}

*ORCID 0000-0003-3934-6589

**ORCID 0000-0003-1442-4472

(C) Myronova Y., 2019.

(C) Siroshtan I., 2019.

Стаття отримана редакиією 02.12.2019 p.

The article was received by editorial board on 02.12.2019

Introduction. Today's market conditions require not only accounting for reflecting the processes of the enterprise's business activity, but also ensuring effective management activities on the basis of a correctly chosen accounting policy and expanding the information circle of consumers. This requires the development of a set of accounting policy elements that will facilitate the application of existing and new approaches to the methodology and organization of accounting and financial reporting, as well as the achievement of the objectives of a particular enterprise.

The current legislation provides for the right to independently develop the accounting policy of the enterprise, taking into account their own industry characteristics and specific activities. However, the accounting policy process has some specificities and problems. This requires the chief accountant to have a competent and responsible attitude to develop accounting policies at the proper level.

The relevance of the topic is due to the fact that accounting policy is an important tool for accounting, ensuring the reliability of financial reporting and the effectiveness of management decisions within the implementation of the overall strategy of the enterprise.

An overview of the latest sources of researches and publications. Significant contribution to the research and development of accounting policy methodology has been made by national scientists, in particular: Veryha Yu. A., Kulyk V.A., Nochovna Yu.O., Ivaniuk S.Yu. [1], Voitenko T.V. [2], Ivchenko L.V. [3], Levchenko N.M, Nesterenko Yu.K. [4], Oliinyk Ya.V. [5], Tsehelnyk N.I. [6], Shchyrba M.T., Shchyrba I.M., Shchyrba M.M. [7] and others.

The main organizational and methodological aspects of the formation of accounting policies of the enterprise: the nature and its purpose, considered in the works by Veryha Yu. A., Kulyk V.A., Nochovna Yu.O., Ivaniuk S.Yu. [1], Voitenko T.V. [2] and Oliinyk Ya.V. [5].

In the monograph by Levchenko N.M. and Nesterenko Yu.K. the theoretical basis of development of methodology of accounting, analysis and audit in the context of dynamic European integration processes is investigated; proposed new approaches to the formation of accounting and information support for managerial decision-making in the context of European integration; practical recommendations for improving tax accounting and control in the context of reforming the tax system of Ukraine in accordance with European standards [4].

Some aspects of the formation of accounting policies of the company for accounting receivables in the system of settlements with customers are considered in the work by Tsehelnyk N.I. [6].

However, the issues of understanding the essence of accounting policy as an integral part of the management system and its purpose in this system remain insufficiently researched.

The purpose of the article. To reveal the essence of the main statements for the formation of accounting policies of the company, which involves the choice of methodological techniques, methods and procedures of organization, accounting and influences the adoption of effective management decisions.

The main material. Accounting is one of the functions of management, because it provides the reliable information needed to make management decisions, external and internal users. Effective and rational accounting organization begins at the enterprise with the formation of its accounting policy. 
At the state level, the order of accounting policy is governed by a number of regulations. The main ones are: The Law of Ukraine «On Accounting and Financial Reporting in Ukraine» [8]; Letter from the Ministry of Finance of Ukraine «On accounting policy» [9]; Accounting provisions (standards); Plan of accounts of accounting of assets, capital, liabilities and business operations of enterprises and organizations [10]; Instructions for the application of the Plan of Accounts for the Accounting of Assets, Capital, Liabilities and Business Transactions of Enterprises and Organizations [11].

According to article 1 of the Law of Ukraine «On Accounting and Financial Reporting in Ukraine», «accounting policy - a set of principles, methods and procedures used by the enterprise to prepare and submit financial statements. Its main purpose is to provide reliable information on the results of financial and economic activities necessary for users of financial statements to make appropriate management decisions». So, accounting policy should be understood as a set of methods of accounting, adopted by the enterprise primary observation, cost measurement, current grouping and summarizing the facts of economic life [1].

The experience of countries with developed market relations shows that an important component of the overall mechanism for managing business activity of enterprises is a well-formed accounting policy. Accounting policy defines the ideology of enterprise management for a long period, promotes accounting and analytical functions in the management of the enterprise, allows to react quickly to changes occurring in the production process, effectively adapt the production system to environmental conditions, reduce economic risk and compete fighting [4]

The formation of accounting policies is quite a responsible task and is to apply the regulatory principles of accounting, preparation and presentation of financial statements, the choice of methods and procedures for processing accounting information.

Formation of accounting policies of the company occurs at three levels:

1) public - a set of procedures for establishing the general principles of accounting in the country through the development of standards, rules and regulations.

2) regional (interstate) - a set of rules, rules and standards used to organize accounting within the associations of countries.

3) local (at the enterprise level) - a set of rules and procedures for the formation of methodological techniques and methods of accounting in the enterprise [5].

The main purpose of accounting policies is to increase the efficiency of the management system due to the high quality of consolidated accounting and analytical information.

The accounting policy of the enterprise should ensure the integrity of accounting and therefore should cover all aspects of the accounting process: methodical, technical and organizational [3].

The methodological aspect determines the options for displaying in accounting and obtaining information about the facts of economic activity, based on alternative methods (techniques) and specific activities of the enterprise. Business accounting policies should reflect only those methodological aspects of accounting entities that have an alternative, or that need to develop accounting methods on their own. The methodological aspect of accounting policy is the most specific. It discloses ways of recognizing and displaying the entity's accounting records within the framework of applicable laws and regulations to formulate financial statements.

The technical aspect of accounting policy includes such components as:

- a chart-account;

- accounting registers and forms of accounting (journal, journal-warrant, journal-master, memorialwarrant, automated (computer);

- charts (charts) of document circulation and accounting information processing technology, incl. using computer hardware;

- composition and procedure of submission of financial and internal reports; the procedure for inventorying assets and liabilities.

The organizational aspect of accounting policy covers the accounting service and its place in the enterprise management system, the order of interaction with other functional and production units. There are defines the form of organization of accounting service in the enterprise. According to item 4 of article 8 of the Law of Ukraine «On Accounting and Financial Reporting in Ukraine» in the following form can be:

- introduction of a position of an accountant in the state of the enterprise or creation of an accounting service headed by the chief accountant;

- use of the services of an accounting specialist registered as an entrepreneur who carries on business without creating a legal entity;

- contractual accounting by centralized accounting or an audit firm; 
- independent accounting and reporting directly to the owner or manager of the enterprise. This form of accounting cannot be applied to entities whose reporting is to be disclosed.

Given the organizational and methodological aspects, it is advisable to divide the process of accounting policy into stages (table 1).

The accounting policy is approved by the order of the head of the enterprise. The accounting policy order is supplemented by the annexes: chart of accounts, workflow schedule, job descriptions, composition of accounting department, composition of internal control apparatus, forms of documents not provided in due course and others.

Table 1

Stages of accounting policy formation

\begin{tabular}{|l|l|}
\hline Stage & \\
\hline Stage 1 & Setting a goal and defining tasks \\
\hline Stage 2 & Selection of the subject of formation \\
\hline Stage 3 & Investigate the factors that may influence accounting policies \\
\hline Stage 4 & Identification of objects \\
\hline Stage 5 & Selection of elements \\
\hline Stage 6 & Documentation \\
\hline Stage 7 & Approval of accounting policies \\
\hline Stage 8 & Implementation and control of the enterprise \\
\hline
\end{tabular}

According to accountants-practitioners, creating accounting policies at the company is a very timeconsuming and responsible process. After all, the company will have to work and account for one year its assets and liabilities in accordance with the developed accounting policy. This requires a more balanced approach to developing accounting policies that are specific to his or her work.

Today, however, a more formal, narrow-minded approach to accounting policies is being increasingly introduced, which is to prepare financial statements in accordance with the general requirements of IAS and external users. This situation is affected both by the lack of sufficient practical experience of management in market conditions and the lack of legislative regulation of this issue.

The main reasons for the formation of accounting policies of the company are:

1. The transition of Ukraine to national accounting standards, based on international developments in this field, provides for the presentation of financial statements more management, information orientation.

2. The concept of accounting in Ukraine formed on the basis of international and national standards, which can be presented as a multi-level structure, which includes:

- micro-economic level - production systems (firms, companies, enterprises, etc.);

- macroeconomic level - national economic branches of the system, financial and industrial systems; systems [5].

- at the global level - international transnational economic, financial and financial-industrial

As each enterprise has its own peculiarities, in developing accounting policies it is necessary to provide those principles, methods and procedures, which are characteristic for its activity. At the same time, the rules that the company develops independently, should not contradict the generally accepted requirements of $\mathrm{P}(\mathrm{S}) \mathrm{BO}$, International Financial Reporting Standards (IFRS) and other regulatory documents for accounting regulation.

Based on the fact that accounting is a component of management information, that is, one way to achieve the goals set before the managed system and to use in planning, forecasting, organizing, regulating, motivating, controlling, analyzing, evaluating and deciding, it can be argued that accounting policies can directly influence the enterprise management process.

In the formulated conditions, the difficulty of developing accounting policies is that accounting professionals must not only understand the theory on which the proclaimed accounting principles are based, but also know to what extent these principles are adhered to in practice and what degree of freedom is allowed in their implementation.

The chosen methods of accounting should provide the accounting process, resulting in a complete and reliable picture of the property and financial condition of the enterprise. However, today, there are a number of problems in accounting policies that Ukrainian businesses faced:

1. Insufficient regulation of the sphere of accounting by the state.

2. Absence of appropriate qualification of accounting policy specialists.

3. Lack of development of accounting policies for management accounting. 
4. There is no uniform structuring of the accounting policy order, incomplete coverage of issues of accounting of individual objects.

Difficulties in accounting policies are that accounting professionals must not only understand the theory on which the proclaimed accounting principles are based, but also know to what extent these principles are applied in practice and what degree of freedom is allowed in their implementation.

Today, it is necessary to rethink the role of accounting policies in the management of the enterprise. It is the managerial orientation of accounting policy that makes sense, since it can fully influence the business processes.

Properly designed accounting policies that meet all the necessary conditions and opportunities for business, should ensure:

- the completeness of all the facts of economic life in the financial statements; importance;

- assets, equity and liabilities based not only on their legal form but also on their economic

- the identity of the analytical accounting data on turnover and balances of synthetic accounting accounts on the 1st of each month, as well as the financial statements of synthetic and analytical accounting data;

- rational accounting, based on the conditions of economic activity and the size of the enterprise.

Given the need for additional measures to ensure the further sustainable development of enterprises in Ukraine and increase the role of their accounting policies in the current economic environment, the main ways to improve it are:

- regulations that determine the essence of accounting policy in Ukraine, unfortunately, do not detail its content, so the implementation is practically unsystematic and not always to the extent that provides a real impact of accounting policies on the formation of costs and income and financial results;

- improvement of national $\mathrm{P}(\mathrm{S}) \mathrm{BO}$ in the formulation and promulgation of accounting policies;

- development and approval in P(S)BO of the unified structure of the accounting policy order for all enterprises, which should consist of three parts (methodological, methodological, organizational) and the standard form of accounting policy order [3].

The methodological part of accounting policy is responsible for how the accounting items will be reported, and the methodological part for how those items will be reflected in the accounts. The organizational part answers the question of exactly how the accounting system will work:

- it is advisable to formulate the accounting policy of enterprises in the light of foreign experience, since the practice of its application in different countries of the world is many years old, and Ukraine is just beginning to reform the accounting.

- it is necessary to develop a program of adaptation of domestic accounting policy to international requirements in order to comply with the basic principles of international reporting standards and ensure Ukraine's accession to the World Trade Organization;

- in order to successfully formulate the content of the accounting policy order, it is advisable that the heads of structural divisions of enterprises and institutions submit to the accounting department proposals and necessary information on the activity of the unit within the specified timeframe;

- to recommend to the Accounting and Reporting Department of the Ministry of Finance of Ukraine to facilitate the organization of competitions and the granting of grants for the best variant of the accounting policy order, presentations and other organizational measures aimed at ensuring the exchange of experience on these issues.

Improvement of regulatory support of accounting policy in Ukraine provides for the development and implementation of the Accounting Standard of the Enterprise Accounting Policies, Methodological Recommendations for Accounting Policies of the Enterprise, as well as the harmonization of national legislation governing the peculiarities of the formation and application of accounting policies for business subjects, as separate provisions of methodological recommendations (instructions, instructions, letters, orders) of the sectoral ministries and departments translate into the requirements of the Accounting Regulations (Standards).

The new $\mathrm{P}(\mathrm{S}) \mathrm{BO}$ «Accounting Policies» shall determine the accounting policy formulation and the general requirements for its elements, except for the requirements for changes in accounting policies provided for $\mathrm{P}(\mathrm{S}) \mathrm{BO} 6$. The introduction of the new $\mathrm{P}(\mathrm{S}) \mathrm{BO}$ «Accounting Policies», which will harmonize all the requirements of the current accounting policy and meet the requirements of IFRS and IAS, will allow the enterprise to formulate such accounting policy, which will enable to form reliable financial statements, will increase business efficiency, facilitate audits, and help resolve conflicts with tax authorities. 
As for the quality of accounting policies, it is necessary to increase it by such criteria as: economic feasibility, completeness, impartiality of accounting policy, consistency with the legislative base, rationality of accounting methods, compliance with company goals and accounting automation.

It is the managers of the company who are responsible for the formation of accounting policies, but the tasks of the manager are not limited. Management should constantly monitor compliance with accounting policies and improve it, which requires additional training for those responsible for the application of accounting policies, to monitor changes in legislation, to inform employees of changes in accounting policies, etc.

Proposed ways to improve the quality of the formation and use of accounting policies at the enterprise, in the future may help to improve the effective functioning of the enterprise, the implementation of business operations on it and their accounting.

Conclusions. Therefore, it can be argued that accounting policies depend on the accounting system, and includes a set of principles, methods, techniques and procedures for reporting as a result of the activity and functioning of the enterprise.

Thus, the information of financial statements as a result of applying accounting policies, on the one hand, is the result of effective or ineffective activities, and on the other - largely depends on how well accounting policies are chosen and the purpose of their formation. Therefore, every effort should be made to ensure that accounting policies are an effective lever to influence the development strategy of the enterprise, accounting is an active participant in the functioning of the enterprise and an element of its management system, and provides users with reliable and impartial information on the status and results of activity enterprises.

So, it is advisable to develop accounting policies not only to influence the accounting system, but also in the direction of adapting it to management needs.

\section{REFERENCES:}

1. The accounting policy of the enterprise / Yu. A. Veryha andothers - Kyiv. : «Center for Educational Literature», 2015.312 p.

2. Voitenko T.V. Accounting Policies - 2010: main. Taxes and accounting. 2010. № 1. P. 16-22.

3. Ivchenko L.V. Conceptual principles of accounting policy. Finance, accounting and auditing. 2009. № 14. P. 246-256.

4. Transformation of accounting and information policy and harmonization of financial reporting, analysis and audit in the context of European integration: monograph / N.M. Levchenko and others; ed. N.M. Levchenko. Zaporizhzhia: Kruhozir, 2015.368 p.

5. Oliinyk Ya.V. Methodological aspects of accounting policies of enterprises. Bulletin of the National University «Lviv Polytechnic». 2012. № 721. P. 206-211.

6. Tsehelnyk N.I. Formation of accounting policy of the enterprise for accounting of receivables in the system of payments with customers. Accounting and Finance. 2014. № 4 (66). P. 77-81.

7.Shchyrba M.T., Shchyrba I.M., Shchyrba M.M. Accounting policy as a tool for organizing management accounting at the enterprise. Economy and society. 2017. № 8. P. 830-837.

8. On Accounting and Financial Reporting in Ukraine: Law of Ukraine of July 16, 1999 № 996-XIV / Verkhovna Rada of Ukraine. URL: https://zakon.rada.gov.ua/laws/show/996-14 (accessed: 10/20/2019).

9. Letter of the Ministry of Finance of Ukraine «On accounting policy» dated 21.12.2005 No. 3134000-10-5 / 27793 / Ministry of Finance of Ukraine. URL:http://195.78.68.18/minfin/control/en/publish/article?art_id=58984\&cat_id=34931 （accessed 20.03.2019).

10. Plan of accounts of accounting of assets, capital, liabilities and business operations of enterprises and organizations: Order of the Ministry of Finance of Ukraine of November 30, 1999 № 291 / Ministry of Finance of Ukraine. URL: https://zakon.rada.gov.ua/laws/show/z0892-99\#n13 (accessed: 10/20/2019).

11. Instruction on the Application of the Plan of Accounts for the Accounting of Assets, Capital, Liabilities and Economic Transactions of Enterprises and Organizations: Order of the Ministry of Finance of Ukraine dated November 30, 1999 No. 291 / Ministry of Finance of Ukraine. URL: https://zakon.rada.gov.ua/laws/show/z0893-99 (accessed: 03/20/2019).

УДК: 657

JEL: M40, M41

Миронова Юлія Юріївна, кандидат економічних наук, доцент. Сіроштан Ілона Олегівна, магістрантка. Національний університет «Полтавська політехніка імені Юрія Кондратюка». Роль 
облікової політики в системі управління підприємством. Розкрито сутність, мету формування облікової політики та іiі управлінську спрямованість. Досліджено аспекти облікового процесу, які впливають на порядок формування облікової політики: методичний, технічний і організаційний. Наведено етапи формування облікової політики, яких доцільно дотримуватися на підприємстві. Правильно розроблена облікова політика повинна забезпечувати: повноту відображення у фінансовій звітності всіх фактів господарського життя; активів, власного капіталу та зобов'язань виходячи не тільки 3 їхньої правової форми, але й 3 їхнього економічного значення; тотожність даних аналітичного обліку оборотам і залишкам рахунків синтетичного обліку на перше число кожного місяця, фінансової звітності даним синтетичного й аналітичного обліку; раціональне ведення обліку виходячи з умов господарської діяльності. 3 огляду на потребу в здійсненні додаткових заходів щодо забезпечення подальшого стійкого розвитку підприємств в Україні та підвищення ролі їх облікової політики в сучасних умовах господарювання основними шляхами ії поліпшення є: внесення змін у нормативно-правові акти, які визначають сутність облікової політики в Україні (не деталізують ії змісту, тому впровадження на практиці здійснюється несистемно і не завжди в обсязі, що забезпечує реальний вплив облікової політики на формування витрат і доходів та фінансових результатів); удосконалення національних П(С)БО в частині формування й оприлюднення облікової політики; розробення та затвердження у П(С)БО єдиної структури наказу про облікову політику для всіх підприємств, яка має складатися із трьох частин (методологічної, методичної, організаційної) й типової форми наказу про облікову політику. Таким чином, інформація фінансової звітності як результату застосування облікової політики, з одного боку, є наслідком ефективної чи неефективної діяльності, а з іншого - значною мірою залежить від того, на скільки вдало обрана облікова політика, та якою є мета іiі формування. Виходячи із цього необхідно докласти максимум зусиль для того, щоб облікова політика була дієвим важелем впливу на досягнення стратегії розвитку підприємства, бухгалтерський облік був активним учасником функціонування підприємства й елементом системи його управління, а також забезпечував користувачів достовірною та неупередженою інформацією про стан і результати діяльності.

Ключові слова: облікова політика, наказ про облікову політику, бухгалтерський облік, управлінський облік.

UDC: 657

JEL: M40, M41

Myronova Yuliia, $\mathrm{PhD}$ (Economics), Associate Professor. Siroshtan Ilona, Master-student. National University «Yuri Kondratyuk Poltava Polytechnic». The Role of Accounting Policy in the Enterprise Management System. The article describes the essence, purpose of accounting policy and its management orientation. The aspects of accounting process that influence the order of accounting policy formation are investigated: methodical, technical and organizational. The stages of accounting policy formation that are advisable to follow at the enterprise are presented. Investigating the existing problems in the formation of accounting policies of the company, the following ways are proposed to solve them: to improve the regulatory framework, since inconsistencies between the acts prevent the enterprise in the formation of effective accounting policies; bring national standards closer to international standards; consider in detail in the normative documents the nature, advantages and disadvantages of various elements of accounting policies. The importance of subordination of accounting policy elements to the objectives of the management process is proved.

Keywords: accounting policy, accounting policy order, accounting, management accounting.
УДК: 657

JEL: M40, M41

Миронова Юлия Юрьевна, кандидат экономических наук, доцент. Сироштан Илона Олеговна, магистрант. Национальный университет «Полтавская политехника имени Юрия Кондратюка». Роль учетной политики в системе управления предприятием. Раскрываются сущность, назначение учетной политики и еe управленческая направленность. Исследованы аспекты учетного процесса, влияющие на порядок формирования учетной политики: методический, технический и организационный. Представлены этапы формирования учетной политики, которых целесообразно придерживаться на предприятии. После исследования существующих проблем в формировании учетной политики компании предлагаются следующие способы их решения: совершенствовать нормативную базу, поскольку несоответствия между актами мешают предприятию в формировании эффективной учетной политики; приблизить национальные стандарты к международным стандартам. Подробно рассмотрены в нормативных документах сущность, достоинства и недостатки различных элементов учетной политики. Обоснована важность подчинения элементов учетной политики целям процесса управления.

Ключевые слова: учетная политика, порядок учетной политики, учет, управленческий учет. 